\title{
The Changing Scenario of Mathematics Formative Assessment in the Era of Globalization
}

\author{
Joezel R. Ambrosio ${ }^{1,2}$, Rhona Lyn R. Bautista ${ }^{1}$, Maria Linda C. Cabillan ${ }^{1, *}$, Nora U. De Vera ${ }^{1}$, John \\ Carlo P. Unson ${ }^{1,3}$, Glory Ann Julien C. Winnan ${ }^{1}$ \\ ${ }^{1}$ Saint Louis University, Baguio City, Philippines \\ ${ }^{2}$ Department of Education, Nueva Vizcaya, Philippines \\ ${ }^{3}$ University of the Cordilleras, Baguio City, Philippines
}

\begin{abstract}
Researches on formative assessment have mentioned its importance in the teaching and learning method. However, there are little to no known researches on formative assessment centered in Mathematics and higher education. This research intends to investigate the awareness and development of formative assessment in undergraduate Mathematics education in a top university in the Philippines, Saint Louis University, currently having more than 30,000 students. Specifically, this research determines the current scenario of formative assessment as it seeks to recognize the adaptation and usage of formative assessment, identify the challenges and opportunities that Mathematics educators face in formative assessment with regards to globalization, and describe the characteristics of the Mathematics educators based on their extent of use of 21 st century formative assessment strategies and tools. Furthermore, this descriptive qualitative research attempts to identify the challenges needed to be overcome by the Mathematics sector to satisfy the globalized skills students needed to attain.
\end{abstract}

Keywords: formative assessment, Philippine Mathematics assessment, higher education.

\section{Introduction}

Assessment, as defined by Huba and Freed (2000), is the process of gathering and discussing information from various sources which enable understanding of what students know, understand, and can do with their knowledge obtained from their educational experiences. Erwin (1991) defines it as the basis for gauging the learning and development of students to be able to increase their learning and development. Palomba and Banta (1999) define it as the analysis and evaluation of information about educational programs undertaken by students for the purpose of improving their learning and development. Allen (2004) defines it as the use of data obtained from observation and experience on student learning for the refinement of programs and improvement of student learning. Among these definitions lie the evaluation of students' knowledge for the improvement and the development of student learning. In addition, Conley (2014) describes assessment as,

"falling along a continuum, ranging from those that measure bits and pieces of student content knowledge to those that seek to capture student understanding in more integrated and holistic ways" (p. 12).

Among the types of assessments, formative assessment fits Conley's description as it is a method of continual evaluation of students' academic needs and development within the classroom (Coffey, 2009), an ongoing analysis of students' learning pace that informs teacher instruction and provide students feedback on a daily basis (Fisher and Frey, 2007), and anything that refers to the various methods that teachers use to evaluate student comprehension, learning needs, and academic progress during a lesson, unit, or course so that adjustments can be made to lessons, instructional techniques, and academic support" (Glossary of Education Reform, 2014) among several definitions. Among these definitions, the idea of assessment during the learning process can be deduced. Researches by Sadler (1989), Black (1993), and Black and William 
(1998) on formative assessment enabled a documentation of its best practices and paved way for further studies in the $21^{\text {st }}$ century. These researches include those by Clark (2012a) who showed that formative assessment builds lifelong competencies (2012b) and ability of students to self-regulate. Hudesman et al. (2013), Nickel (2013), and Dunn and Mulvenon (2009) examined the effect of formative assessment in students' performances. Dekker and Feijs (2005) discussed changes in teachers' attitudes towards assessment and classroom practice as a result of their participation in the professional development program while, Frunza (2014) discussed the advantages and barriers of formative assessment in the teaching-learning activity. In addition, Magno and Lizada (2015) provide nine principles of formative assessment serving as a set of expectations for teachers while Yorke (2003) puts emphasis on the use of formative assessment as a way of improving instruction in higher education. In the Philippines, the Department of Education (DepEd Order no. 8, s. 2015) gave light on formative assessment as it is translated into national and educational policies. Further, they have advised (DepEd Advisory no. 1, s. 2016) that ongoing research is conducted by the Assessment, Curriculum, and Technology Research Centre (ACTRC), a partnership between the University of the Philippines and the University of Melbourne.

Globalization, on the other hand, is the process of interaction and collaboration with people of different nations (Levin Institute, 2015), a widening and growing of the impact of world-wide connectedness (Goldblatt et al., 1999), and any reform or structure that transcends national borders (Astiz, 2002) among several definitions. Thus, it can be deduced that globalization is the increasing interaction and collaboration among nations. Furthermore, globalization in the $21^{\text {st }}$ century is reaching almost all countries - few places can elude contemporary trends, and innovations and practices seem to spread even faster due to modern technology (Altbach, 2004). Hence, it can be said that the $21^{\text {st }}$ century is the era of globalization. Even the education sector is not exempted from its impacts as stated in both researches by Luckett and Sutherland (2000) and Vaira (2004), globalization has pressured higher education institutions towards development. These now enable universities worldwide to be able to interact and collaborate with one another. In line with Mathematics, Atweh and Clarkson (2001) state that these are made possible through technological advancements as Mathematics educators become more reliant on the Internet to keep in touch with some international publications and the few conferences that they are able to attend. Furthermore, Sinclair (2014) traced some of the influential ideas and motivations that have shaped a large part of the research on the use of new technologies in Mathematics education over the past 40 years.

These elaborations above can now be synthesized in the context of undergraduate Mathematics education. Formative assessment has always played its role in classrooms as it is intended to gauge students' understanding of a given subject matter. Mathematics is no exempt as a scope of this assessment. As globalization widens its horizons, changes are made and incorporated in Mathematics formative assessment strategies as well. Ebeid asserted that there is a necessity of addressing the need to shift the culture of Mathematics teaching and learning to suit the features of globalization (2004). Furthermore, Pellegrino mentions that assessment can serve as a positive influence on attaining $21^{\text {st }}$ century learning goals (2015) whereas, Conley mentions that the pursuit of deeper learning will mandate greater emphasis on formative assessments that signal to students and teachers what they must do to attain college and career readiness (2014). Wiliam (2005) concluded that focusing on the use of day-to-day formative assessment is one of the most powerful ways of improving learning in the Mathematics classroom.

A university in Baguio City, Philippines, namely Saint Louis University and currently having more than 30,000 students, is regarded as a top center of excellence as it meets international standards in tertiary education (Saint Louis University, n.d.). The university has managed to collaborate with different nations one of which is through the exchange student program. In line with Mathematics education, its instructors strive to provide good quality education enabling their students to excel.

Stiggins (2005) stated that formative assessment is intended to enhance student learning, Belaaouad et al. (2015) concluded that formative assessment can help teachers anticipate in advance to fill the gaps and change the methods in the learning process, Black et al. (2004) concluded that improvement of formative assessment is beneficial not only to education but also to rankings of performance. Atweh and Clarkson (2002) noted the divergence of Mathematics education curricula around the world where the curriculum of 
one country may vary from another. Altogether, the teachers' ways of enhancing student learning in Mathematics assessment for the improvement of student performance may vary from one country to another.

Hence, this research is intended for the investigation of the awareness of Mathematics instructors and the development of Mathematics formative assessment in the Philippines, particularly in Saint Louis University, Baguio City. Specifically, the study seeks to determine the current scenario, the challenges, and the future directions of Mathematics formative assessment in Saint Louis University, Baguio City as well as significant differences among those who have taught undergraduate Mathematics for less than 10 years and those who have taught for at least 10 years with their extent of use of formative assessment tools.

\section{Materials and Methods}

This combined qualitative and quantitative research depicts the current state and the future directions of Mathematics formative assessment which satisfy the globalized skills students needed to attain. Further, this research was conducted at Saint Louis University, Baguio City where the respondents were 43 among 49 undergraduate Mathematics instructors coming from the schools of Computing and Information Sciences, Engineering and Architecture, and Teacher Education. The instructors, employing various methods of teaching undergraduate Mathematics subjects, having a minimum load of 15 units of Mathematics subjects, and having agreed to take part of this research, will be the most suitable respondents. These instructors were grouped according to years of teaching undergraduate Mathematics: those who have taught for less than 10 years and those who have taught for at least 10 years. Such classification was made as 10 years is enough for an undergraduate Mathematics instructor to manifest dedication for service - one who has worked for 10 years in the institution is given honor in due time. Data were gathered by means of questionnaires and interviews; these data were treated with confidentiality.

The first part of the questionnaire entailed the respondents to answer items on a 4-point scale with respect to their frequency of use of formative assessment tools. These tools were classified with respect to the $21^{\text {st }}$ century as follows: the traditional and the $21^{\text {st }}$ century, where traditional formative assessment is highly nonreliant of technology and is widely practiced before the turn of the millennium, while the $21^{\text {st }}$ century formative assessment highly makes use of $21^{\text {st }}$ century skills (referred to Thoughtful Learning, n.d.), which imply the need for both teachers and students to be technology savvy. OCPS Curriculum Services and Lambert's (2012) list of formative assessment tools or strategies for teachers and students served as the basis for traditional formative assessment tools while Davis's (2015), Brown's (2015), and PDE Mentors' (2009) lists served as the bases for $21^{\text {st }}$ century formative assessment tools. Since the $21^{\text {st }}$ century is the era of globalization, this approach would be necessary in determining the current scenario of Mathematics formative assessment in Saint Louis University and in the era of globalization. The data obtained from the 4point scale items enabled the gathering of information on the current state of Mathematics formative assessment and whether the Philippines, let alone, Saint Louis University, is geared towards the use of technology in undergraduate Mathematics education or not. The last part of the questionnaire entailed the respondents to answer questions in the form of short essays. Questionnaires that were neither answered fully nor returned were treated null and void. The data obtained from the short essays would be essential in determining the challenges that hinder the respondents in using formative assessment tools and in determining the future direction of Mathematics formative assessment in Saint Louis University and in the era of globalization.

Results obtained from questionnaires were collated according to frequency of use of formative assessment tools and the respondents' number of years of teaching undergraduate Mathematics, presented in tabular form, and interpreted as follows:

\begin{tabular}{|c|c|c|c|}
\hline OPTION & SCALE & ASSIGNED WEIGHT & RANGE \\
\hline Always & A & 4 & $3.26-4.00$ \\
\hline Often & B & 3 & $2.51-3.25$ \\
\hline Seldom & C & 2 & $1.76-2.50$ \\
\hline Never & D & 1 & $1.00-1.75$ \\
\hline
\end{tabular}


Furthermore, these tools were grouped according to approach wherein the traditional formative assessment tools were grouped according to Pen and Paper, Oral/Visual, Game - Oriented, and a combination of either or all three approaches; these tools were grouped according to the medium of response. The $21^{\text {st }}$ century formative assessment tools were grouped according to those that are technology-based and those that are non-technology-based tools. Respondents' answers were averaged per approach and overall, in terms of the traditional and $21^{\text {st }}$ century formative assessment tools. Eventually, these averages were then averaged once more with respect to the respondents' groups.

Independent $\mathrm{t}$-test samples and non-parametric independent samples were used to determine significant differences among those who have taught undergraduate Mathematics for less than 10 years and those who have taught for at least 10 years with their extent of use of formative assessment tools. These tools were used since both sought to compare data from the said groups.

Structured interviews were conducted with 5 respondents who had the greatest number of $21^{\text {st }}$ century formative assessment tools used and 5 respondents who had the least to none $21^{\text {st }}$ century formative assessment tools used. These structured interviews were recorded and the data obtained enabled the gathering of insights on where Mathematics formative assessment in the Philippines, let alone, Saint Louis University, is headed in the era of globalization.

\section{Results and Discussion}

Among the 43 questionnaires, 5 of these were considered null and void. In turn, these 38 respondents' answers gave the findings as shown on Table 1.

Table 1: Presentation of Data

\begin{tabular}{|c|c|c|c|c|c|c|}
\hline & \multicolumn{2}{|c|}{ Less than 10 years } & \multicolumn{2}{|c|}{10 years and above } & \multicolumn{2}{|c|}{ Findings } \\
\hline & Weight & Description & Weight & Description & p - value & Significance \\
\hline \multicolumn{7}{|l|}{ Traditional } \\
\hline Pen and Paper & 2.20 & $\mathrm{C}$ & 2.14 & $\mathrm{C}$ & $\begin{array}{c}0.902(> \\
0.05)\end{array}$ & $\begin{array}{c}\text { Not } \\
\text { significant }\end{array}$ \\
\hline Oral/Visual & 2.15 & $\mathrm{C}$ & 1.83 & $\mathrm{C}$ & $\begin{array}{c}0.059(> \\
0.05)\end{array}$ & $\begin{array}{c}\text { Not } \\
\text { significant }\end{array}$ \\
\hline $\begin{array}{l}\text { Game - } \\
\text { Oriented }\end{array}$ & 1.42 & $\mathrm{D}$ & 1.47 & $\mathrm{D}$ & $\begin{array}{c}0.847(> \\
0.05)\end{array}$ & $\begin{array}{c}\text { Not } \\
\text { significant }\end{array}$ \\
\hline Combined & 1.83 & $\mathrm{C}$ & 1.69 & $\mathrm{D}$ & $\begin{array}{c}0.783(> \\
0.05)\end{array}$ & $\begin{array}{c}\text { Not } \\
\text { significant }\end{array}$ \\
\hline Average & 1.90 & $\mathbf{C}$ & 1.78 & $\mathbf{C}$ & $\begin{array}{c}0.470(> \\
0.05)\end{array}$ & $\begin{array}{c}\text { Not } \\
\text { significant }\end{array}$ \\
\hline \multicolumn{7}{|l|}{ 21st Century } \\
\hline Technology & 1.50 & $\mathrm{D}$ & 1.49 & $\mathrm{D}$ & $\begin{array}{c}0.686(> \\
0.05)\end{array}$ & $\begin{array}{c}\text { Not } \\
\text { significant }\end{array}$ \\
\hline $\begin{array}{l}\text { Non - } \\
\text { technology }\end{array}$ & 1.49 & $\mathrm{D}$ & 1.28 & $\mathrm{D}$ & $\begin{array}{c}0.160(> \\
0.05)\end{array}$ & $\begin{array}{c}\text { Not } \\
\text { significant }\end{array}$ \\
\hline Average & 1.50 & D & 1.39 & $\mathbf{D}$ & $\begin{array}{c}0.388(> \\
0.05)\end{array}$ & $\begin{array}{c}\text { Not } \\
\text { significant }\end{array}$ \\
\hline
\end{tabular}

Although Mina (2004) acknowledges the decrease of the use of the traditional formal teaching of Mathematics and the increase of use of technology, the respondents' answers have shown otherwise. This is noted as the table shows that both groups are more adept with traditional formative assessment tools, specifically, the Pen and Paper and Oral/Visual approaches. In addition, those who have taught undergraduate Mathematics for less than 10 years are also adept with the use of the Combined approach tools. Surprisingly, no significant differences were noted among both groups with their extent of use of formative assessment tools. Furthermore, even though both groups are more adept with technology based, 
$21^{\text {st }}$ century formative assessment tools, they are still highly held back with its use in the era of globalization.

The respondents have justified these findings as they cited the following areas of challenges that have been hindering them in using formative assessment tools, mostly the $21^{\text {st }}$ century formative assessment tools: (a) knowledge, (b) time, (c) facilities, and (d) compatibility.

Knowledge. Some respondents have acknowledged that they are not familiar with the formative assessment tools that are practiced. Those who were interviewed had varying degrees of knowledge when asked what they knew about formative assessment; only one had a full grasp of its concept stating that "it happens during class discussions where there is immediate feedback and you can check on the level of understanding of the students". This is supported by Dixon and Williams (2001) who mentioned that formative assessment is not well understood by teachers and is weak in practice; teachers are still confused about the nature, purpose, and effect of formative assessment. Clark (2012a) expounds on their findings by saying that,

\begin{abstract}
"teachers attributed great importance to formative assessment and its potential to enhance instruction and develop essential lifelong learning competencies among students. However, when asked to articulate their practice in more detail, they were not able to explain clearly how they used the assessment information gained to enhance children's learning. If practitioners are to conceptualize formative assessment practices as creative and participatory, they need time to translate theory into practice". (p. 27)
\end{abstract}

A respondent suggested that seminars on formative assessment ought to be conducted. This is at par with Macintyre et al. (2007) who recommended that teachers are trained so they develop insights in four key areas: seeing, relational knowing, mindful embodiment, and continual assessment. Black et al. (2003) found that teachers who received training in formative assessment and were provided with ongoing, collaborative support were able to make substantial changes within their classrooms. Further, Black and William (1998) mentioned that there are positive effects on student learning and achievement when teachers learn to utilize formative assessment practices as a result of appropriate professional development.

Time. A regular Mathematics class in Saint Louis University, Baguio City is allotted 3 hours a week - that is, 1 hour every other day. One of the respondents wrote that "with the limited number of hours given for each of the courses and subjects, the use of formative assessment tools may consume a sizeable amount of time which is supposedly allotted for lectures and discussions". This was supported by another respondent who mentioned that "formative assessment tools are time consuming if all are incorporated in the class activities given that each topic has its own time frame". Two contributing factors to this area of challenge are: (a) student population and (b) college environment.

Student Population. A regular Mathematics class consists of 50 students and "the implementation of formative assessments takes time for such a large population", according to a respondent. Formative assessment aims to help students to focus on the learning goal and to work out with students to reach the learning goal and makes use of feedback of results (Magno and Lizada, 2015). This may warrant teachers to give their attention to each of the 50 students in one classroom, which is highly timeconsuming.

College Environment. "The academic scenario and environment [in college] is very much different from that of the high school learning environment where teachers get to meet the students for almost an entire year". This means that teachers in high school, and even elementary, get to have more time to assess student learning. Given limited time in college, not all formative assessment tools may be used and maximized.

Facilities. As the $21^{\text {st }}$ century is highly reliant on technology and enabling globalization to widen its scope, formative assessments are not exempted. As formative assessment makes use of feedback of results (Magno and Lizada, 2015), the availability of facilities could make this feature more efficient and realized. Findings 
made by Adams and Porter (2014) saw that the use of technologies on formative assessment has enabled turn - around time in submission of school work and feedback has been greatly reduced. Furthermore, the use of multimedia feedback may be a means of reducing the time taken to give quality personalized feedback while increasing student satisfaction and knowledge retention. However, respondents are hindered due to lack of these facilities. According to Stošić (2015), the teaching process is still dominated by traditional methods due to computers still not widely used in many schools. A respondent mentioned that lack of available resources and the presence of poor internet connection discourage them in using such powerful tools of assessment in classes due to a limited ratio among the faculty and the number of projectors. This is in turn supported by another respondent who mentioned that "lectures must be done in smart classrooms with, the presence of computers, multimedia and very fast internet connection".

Compatibility. Compatibility is based on how formative assessment tools are fit for students' learning and for Mathematics classes. Various respondents mentioned that "formative assessment is not applicable to all students" since "[some] students cannot cope with the new assessment being used to them" and "tend to depend on the given examples of the instructor [wherein] they memorize the solution without understanding the concept and exploring more examples". In addition, a respondent mentioned that it is "sad to say that there are students that are not fully adapted to being online - a constraint to look into for fair evaluation". Some respondents have acknowledged that these tools are "useful in some subjects but most of the methods are neither applicable nor suitable in teaching Mathematics" as "some of the methods presented are impractical". Formative assessment makes use of continuous and multiple forms of assessment (Magno and Lizada, 2015). This may challenge teachers in implementing multiple formative assessment tools that satisfy both this description and compatibility with students or Mathematics altogether.

Despite these challenges, most of the respondents said yes when asked of their willingness to use $21^{\text {st }}$ century formative assessment tools given favorable circumstances wherein challenges are provided solutions. A respondent mentioned that, he "would love to learn and use such tools if it promotes a more conducive learning for the students". Another mentioned that "formative assessment may make classroom learning more fun". In addition, a respondent "believe[s] in the spirit and the wisdom of the $21^{\text {st }}$ century formative assessment that would help further the discussion of the lessons and for the students to understand better the topic". Hence, it can be deduced that the respondents are gearing towards the use of $21^{\text {st }}$ century formative assessment tools.

\section{Conclusions}

The respondents were more adept with the traditional formative assessment tools, specifically the Pen and Paper and Oral/Visual approaches. In addition, those who have taught for 10 years are also more adept with the Combined approach tools. Furthermore, there were challenges cited that hindered the respondents from the use of these tools, especially the $21^{\text {st }}$ century formative assessment tools. These tools were classified as: (a) knowledge, (b) time, (c) facilities, and (d) compatibility. Overall, knowledge and facilities prove to be the most crucial factor to consider with respect to the use of $21^{\text {st }}$ century formative assessment tools. Knowledge is very crucial in the era of globalization as it is most essential in the exchange of ideas. Facilities, particularly computers, multimedia, and the internet, are much relied upon in this era of globalization. Both are interrelated given that the absence of relevant knowledge would make the presence of facilities useless and the absence of facilities would make the presence of relevant knowledge difficult to be shared. Most $21^{\text {st }}$ century formative assessment tools require the use of such facilities. However, since lacking, the respondents are left with no choice but to employ traditional methods and to collaborate among themselves in the university. Hence, Mathematics formative assessment in Saint Louis University, Baguio City is still insufficiently equipped when it comes to the use of $21^{\text {st }}$ century formative assessment tools and the presence of such facilities could make a big difference - Stošić (2015) also acknowledges this as a problem. These findings are limited within undergraduate Mathematics education in Saint Louis University, Baguio City and do not generalize nor imply that these findings are true for other universities in the Philippines. Since this study has only focused on one university where respondents were undergraduate Mathematics instructors, extensive studies within other universities, in the Philippines and abroad, may be done to make further generalizations where students enrolled in undergraduate Mathematics may also be 
employed as respondents. More detailed research, by investigating the formative assessments in each subject in the undergraduate mathematical field, may also be conducted.

\section{Acknowledgments}

The researchers would like to express their thanks and appreciation to their family members who provided them so much support, concern, and prayers. The researchers would also like to thank one another for their endless support system in order to be able to make this paper. Above all, the researchers would want to thank the Lord Almighty for all the possibilities He had manifested in this paper.

\section{References}

1. Adams, N. \& Porter A. (2014). Evolving formative assessment for and with ubiquitous technologies. $12^{\text {th }}$ International Conference: The Future of Mathematics Education in a Connected World, 1-7.

2. Allen, M.J. (2004). Assessing general education programs. Boston, Massachusetts: Anker Publishing Company, Inc.

3. Altbach, P.G. (2004). Globalization and the university: myths and realities in an unequal world. Tertiary and Education Management.

4. Astiz, M. et al. (2002). Slouching towards decentralization: consequences of globalization for curricular control in national education systems. Comparative Education Review, 46(1), 66-88.

5. Atweh, B. \& Clarkson, P. (2001). Mathematics educators' views about globalization and internationalization of their discipline: preliminary findings. Proceedings of the annual conference of the Australian Association for Research in Education.

6. Atweh, B. \& Clarkson, P. (2002). Globalized curriculum or global approach to curriculum reform in mathematics education. General Issue: Asia Pacific Education Review, 3(2), 160-167.

7. Belaaouad, S. et al. (2015). The impact of formative assessment on the learning process and the unreliability of the mark for the summative evaluation. Procedia - Social and Behavioral Sciences, 197, $680-685$.

8. Black, P.J. (1993). Formative and summative assessment by teachers. Studies in Science Education, 21(1), 49-97.

9. Black, P. \& Wiliam, D. (1998). Assessment and classroom learning. Assessment in Education, 5(1), $7-71$.

10. Black, P. et al. (2003). Assessment for learning: putting it into practice. Buckingham, UK: Open University Press.

11. Black, P. et al. (2004). Teachers developing assessment for learning: impact on student achievement. Assessment in Education: Principles, Policy \& Practice, 11(1).

12. Brown, P. (2015). _Edtech tools get creative with formative assessments. Retrieved from https://www.edsurge.com/news/2015-01-12-edtech-tools-to-get-creative-with-formative-assessments.

13. Clark, I. (2012a). Formative assessment: a systematic and artistic process of instruction for supporting school and lifelong learning. Canadian Journal of Education, 35(2), 24-40.

14. Clark, I. (2012b). Formative assessment: Assessment is for self-regulated learning. Educational Psychology Review, 24, 205-249.

15. Coffey, H. (2009). Formative assessment. Retrieved from http://www.learnnc.org/lp/pages/5212.

16. Conley, D. T. (2014). A new era for educational assessment. Deeper Learning Research Series.

17. Davis, V. (2015). 5 Fantastic, Fast, Formative Assessment Tools. Retrieved from http://www.edutopia.org/blog/5-fast-formative-assessment-tools-vicki-davis.

18. Dekker, T. \& Feijs, E. (2005).Scaling up strategies for change: change in formative assessment practices. Assessment in Education, 12(3), 237-254.

19. DepEd Advisory no. 1, s. 2016. Research project on formative assessment in the Philippines of the Assessment, Curriculum, and Technology Research Centre (ACRTC).

20. DepEd Order no. 8, s. 2015. Policy guidelines on classroom assessment for the $\mathrm{K}$ to 12 basic education program.

21. Dixon, H., \& Williams, R. (2001). Teachers' understandings of formative assessment. Paper presented at the Annual Conference of the British Educational Research Association.

22. Dunn, K. E. \& Mulvenon, S. W. (2009). A critical review of research on formative assessment: the limited scientific evidence of the impact of formative assessment in Education. Performance 
Assessment Research \& Evaluation, 14, 7, 2.

23. Ebeid, W. \& Gholam, G.K. (2004). A paradigm shift in mathematics education in the service of sustainable development. Paradigm Shift in Mathematics Education, 19, 1-2.

24. Erwin, T. (1991). Assessing student learning and development: A guide to the principles, goals, and methods of determining college outcomes. San Francisco, California: Jossey-Bass Inc., Publishers.

25. Fisher, D. \& Frey, N. (2007). Checking for understanding: Formative assessments for your classroom. Alexandria, Virginia: ASCD.

26. Frunza, V. (2014). Advantages and barriers of formative assessment in the teaching-learning activity. Procedia - Social and Behavioral Sciences, 114, 452 - 455.

27. Glossary of Education Reform (2014). Formative Assessment. Retrieved from http://edglossary.org/formative-assessment/.

28. Goldblatt, D. et al. (1999). Globalization. Global Transformations. Retrieved from https://www.polity.co.uk/global/globalization-oxford.asp.

29. Huba, M. \& Freed, J. (2000). Learner-centered assessment on college campuses: Shifting the focus from teaching to learning. Boston, Massachusetts: Allyn and Bacon.

30. Hudesman, J. et al. (2013). Using formative assessment and metacognition to improve student achievement. Journal of Developmental Education, 37(1), 2-13.

31. Lambert, K. \& OCPS Curriculum Services (2012). Formative assessment strategies. Retrieved from https://www.utwente.nl/en/examination/faq-testing-assessment/60formativeassessment.pdf.

32. Levin Institute (2015). What is globalization. Retrieved from http://www.globalization101.org/.

33. Luckett, K. \& Sutherland, K. (2000). Assessment practices that improve teaching and learning [Abstract]. African Higher Education Research Online, 98-130.

34. Macintyre, L. M. et al. (2007). Formative assessment requires artistic vision. International Journal of Education \& the Arts, 8(4), $1-23$.

35. Magno, C. \& Lizada, G. (2015). Features of classroom formative assessment. Educational Measurement and Evaluation Review, 6, 23-31.

36. Mina, F.M. (2004). Some remarks on the future of mathematics education. Proceedings of the International Conference of the Mathematics Education into the $21{ }^{\text {st }}$ Century Project on "The Future of Mathematics Education".

37. Nickel, J. (2013). Formative assessment and syntheses in reflection journals. Transformative Dialogues: Teaching \& Learning Journal.

38. Palomba, C. \& Banta, T. (1999). Assessment essentials: Planning, implementing, and improving assessment in higher education. San Francisco, California: Jossey-Bass Inc., Publishers.

39. PDE Mentors (2009). Formative assessment tools for $21^{\text {st }}$ century learning. Retrieved from https://www.sde.idaho.gov/site/assessment/formativeInterim/docs/FormativeAssessmentTools.pdf.

40. Pellegrino, J.W. (2014). Assessment as a positive influence on 21st century teaching and learning: A systems approach to progress. Psicología Educativa, 20, 65-77.

41. Sadler, R. (1989). Formative assessment and the design of instructional systems [Abstract]. Instructional Science, 18(2), 119-144.

42. Saint Louis University (n.d.). About SLU. Retrieved from https://www.slu.edu.ph/index.php/factsand-figures.

43. Sinclair, N. (2014). Generations of research on new technologies in mathematics education. Teaching Mathematics Applications, 33(3), 166-178.

44. Stiggins, R. (2005). From formative assessment to assessment for Learning: A path to success in standards-based schools. The Phi Delta Kappan, 87(4), 324-328.

45. Stošić, L. (2015). The importance of educational technology in teaching. International Journal of Cognitive Research in Science, Engineering, and Education, 3(1), 111-114.

46. Thoughtful Learning. (n.d.). What are $21^{\text {st }}$ century skills? Retrieved from https://k12.thoughtfullearning.com/FAQ/what-are-21st-century-skills.

47. Vaira, M. (2004). Globalization and higher education organizational change: A framework for analysis [Abstract]. Higher Education, 48(4), 483-510.

48. Wiliam, D. (2005). Keeping learning on track: formative assessment and the regulation of learning. Making Mathematics Viral: Proceedings of the Twentieth Biennial Conference of the Australian Association of Mathematics Teachers. 
49. Yorke, M. (2003). Formative assessment in higher education: moves toward theory and the enhancement of pedagogic practice. Higher Education, 45(4), 477-501. 